Proc. Estonian Acad. Sci. Biol. Ecol., 2002, 51, 2, 91-102

\title{
The contribution of nonindigenous Cercopagis pengoi (Ostroumov) in the mesozooplankton community and its population structure in the Gulf of Riga
}

\begin{abstract}
Solvita Strake
Department of Marine Ecology, Institute of Aquatic Ecology, University of Latvia, Miera 3, Salaspils, LV 2169, Latvia; solvita@ hydro.edu.lv

Received 28 March 2001, in revised form 1 October 2001

Abstract. The nonindigenous predatory cladoceran Cercopagis pengoi forms a permanent population in the whole Gulf of Riga. During the investigation period 1997-99, the density of C. pengoi showed an increasing tendency with the highest recorded abundance $\left(5790\right.$ ind. $\left.\mathrm{m}^{-3}\right)$ in the littoral zone. Maximum values were often found in the eastern part of the Gulf, where the highest water temperatures and lower salinities were recorded. Total zooplankton abundances were higher in the south-eastern and central parts of the Gulf. C. pengoi densities were higher above the thermocline, where over $50 \%$ of the population consisted of juveniles, than beneath it. In the warm upper water layers ( $0-4 \mathrm{~m})$ juveniles formed up to $92 \%$ of the total population density. Presence of $C$. pengoi in the littoral zone seems to be unfavourable for microzooplanktonic rotatorians and nauplii of copepods.
\end{abstract}

Key words: Baltic Sea, Gulf of Riga, mesozooplankton, Cercopagis pengoi, population structure, nonindigenous species.

\section{INTRODUCTION}

Nearly 100 introduced species have been recorded in the Baltic Sea since 1820. This number increased very fast during the last 30 to 40 years (Gollasch \& Leppäkoski, 1999), but there may be several unknown introductions from older times (Leppäkoski, 1991). First reviews of the introduced species in the Baltic Sea appeared in the 1950s (Nikolaev, 1951; Segerstråle, 1957) and were completed by Leppäkoski (1984) and Jansson (1994). Approximately 2/3 of the introduced species (altogether about 90) in the Baltic Sea have been established as selfreproducing populations (Gollasch \& Leppäkoski, 1999).

Fresher coastal waters are more suitable for introduction of new species compared with other parts of the Baltic Sea. Most exotic species are found in littoral subsystems (Leppäkoski, 1984), whereas the deep bottoms and the pelagic part were practically free from them until the 1980s (Leppäkoski, 1991). 
During the 20th century, 18 exotic species were found in the Gulf of Riga and 10 of them form stable populations (BMB WG NEMO, 2001). The North American polychaete Marenzelleria viridis should be regarded as the most important species. It arrived in the Gulf of Riga in 1988 (Lagzdins \& Pallo, 1994), but was first recorded in the southern Baltic in 1985. The zebra mussel Dreissena polymorpha, whose abundance and biomass were highest in 1985-89 (G. Lagzdins, unpubl. data), could cause a change in the food web structure of the bottom-living macrofauna system. In 1993, a new species of the genus Leimia dominated in the harpacticoida fauna close to the mouth of the Daugava River (Pallo et al., 1998). The dinoflagellate Prorocentrum scutellum, never found in the Gulf of Riga, occurred in 1993-94 in large numbers in the coastal zone of Pärnu Bay (Tenson, 1995). A few specimens of the potentially toxic species Prorocentrum minimum were found in the Gulf of Riga in 1998 (I. Ledaine, unpublished data). The recent invasion of benthos species may change the sea bottom ecosystem by decreasing its biodiversity, and plankton species could be connected to the decline in the fish catches.

The predatory cladoceran Cercopagis pengoi gradually became an important component in the Cladocera group of the plankton community in the Gulf of Riga at the end of the 1990s (this study). Recorded in 1992 with a few specimens (Ojaveer \& Lumberg, 1995) in Pärnu Bay, the population of $C$. pengoi gradually increased in the following years, but a declining tendency of the abundance of small-sized Bosmina c. maritima was observed in the NE Gulf of Riga (Ojaveer et al., 2000). Therefore, during the last ten years the problems caused by the introduction of nonindigenous species have increased markedly.

In this study I analyse the contribution of Cercopagis pengoi to the total zooplankton community and its spatio-temporal distribution along the salinity, depth, and eutrophication gradients and illustrate its population structure in the Gulf of Riga.

\section{MATERIAL AND METHODS}

Zooplankton surveys were carried out along three transects of the Gulf of Riga in 1997 (Fig. 1) and 1998 and in the littoral zone (1 m depth) around the Gulf in 1999. Investigations concerning spatio-temporal distribution of the total zooplankton community, including Cercopagis pengoi, were made during 17-29 July and 1-10 October 1997, 13-28 August 1998, and 7-9 July 1999, respectively. Samples from 13 pelagic stations were taken with a Judy net of $100 \mu \mathrm{m}$ mesh size. The material from 10 littoral zone stations was collected with an Apstein net of $55 \mu \mathrm{m}$ mesh size. Samples were preserved in formalin with the final concentration of $4 \%$.

The depths for the zooplankton samples were chosen according to the stratification of the water column and CTD measurements. As a result, the water column was divided into two layers in summer periods: upper mixed layer above the thermocline and deep water layer beneath the thermocline. In summer 1998 


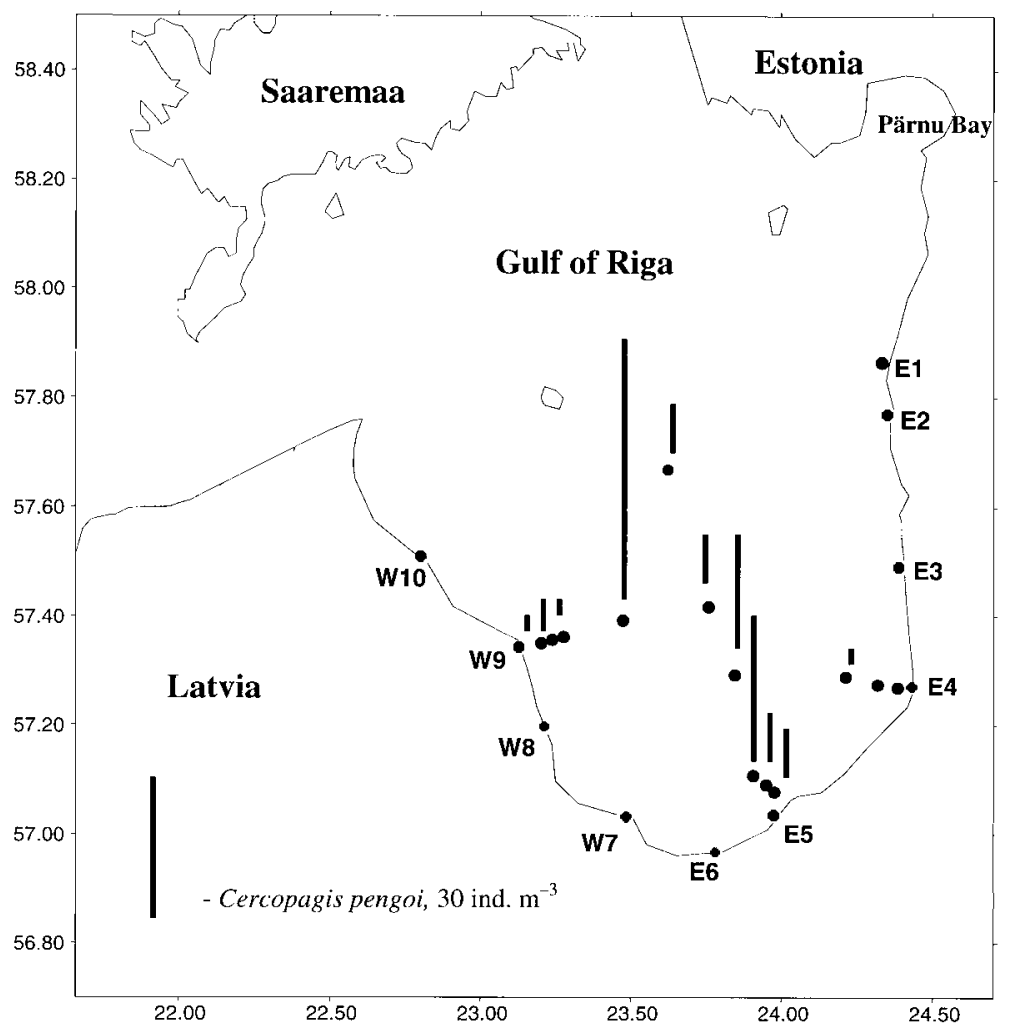

Fig. 1. Zooplankton sampling sites and distribution of Cercopagis pengoi in the Gulf of Riga above the thermocline in summer 1997.

three-layer stratification was formed due to the temperature regime at the eastern transect. Above the thermocline the temperature was $16.6^{\circ} \mathrm{C}$, but in the upper thin $(0-4 \mathrm{~m})$ water layer the temperature was $17.6^{\circ} \mathrm{C}$ (i.e., a three-layer structure was caused by thermal stratification). Therefore, samples were taken from each of the three layers separately.

The zooplankton was analysed in laboratory under binocular microscope. Three to five dominating species in the sample were counted to 100 individuals, and the abundance of individuals was calculated per $\mathrm{m}^{-3}$. The zooplankton organisms were identified up to species level and classified into Rotatoria, Cladocera, and Copepoda. Copepoda were sorted according to the following categories: nauplii, copepodites, adult males and females.

Samples with $C$. pengoi were once more analysed and all individuals per sample counted under BX50 stereo microscope. Analysis of the C.pengoi population structure was based on the following groups: juveniles (sex was not determined), males, and parthenogenetic and gametogenetic females. The mesozooplankton biomasses (wet weight) were calculated from the known individual 
masses (Ojaveer, 1997) and for C. pengoi biomass calculations a standard weight of $0.3 \mathrm{mg}$ was used (Antsulevich \& Välipakka, 2000). A total of 51 zooplankton samples were examined.

\section{RESULTS}

\section{Hydrographical parameters}

Stratification of the water column was pronounced at all pelagic stations during the warm season, with a thermocline at a depth of 8 to $15 \mathrm{~m}$. In the upper water layer, the temperature was on average $18.6^{\circ} \mathrm{C}$ (range $16.9-20.5^{\circ} \mathrm{C}$ ) in July 1997. In August 1998, the average upper water layer temperature was only $16.3^{\circ} \mathrm{C}$ (range $15.8-17.6^{\circ} \mathrm{C}$ ). In both years the temperature fluctuated beneath the thermocline on the average from 4.2 to $2.5^{\circ} \mathrm{C}$.

The salinity was slightly higher at the westernmost transect with more expressed influence from the open sea in comparison with the Daugava River and the eastern transects of the Gulf of Riga. In the upper water layer, salinities were lowest at stations with river influence (3.84-4.00\%o). Higher salinities (5.92-6.59\%o) were recorded in the deeper water layers at all transects.

The autumn cruise (1-10 October 1997) showed a completely mixed water column down to $40 \mathrm{~m}$ at all stations. According to the temperature and salinity distribution the water of the basin was homogeneous both horizontally and vertically $\left(12.0-10.7^{\circ} \mathrm{C}\right.$ and $5.62-5.72 \%$, respectively). The salinity was lower (4.39-4.92\%o) only for the plume area of the Daugava River.

In the littoral zone the mean water temperature and salinity recorded on 7-9 July 1999 were higher in the western part than in the eastern part of the Gulf of Riga $-20.1{ }^{\circ} \mathrm{C}, 4.65 \%$ and $21.6^{\circ} \mathrm{C}, 4.20 \%$, respectively. However, the clearly lower salinity at a few stations (E4, E6) showed the influence of three rivers falling into the southern part of the Gulf of Riga (Fig. 2).

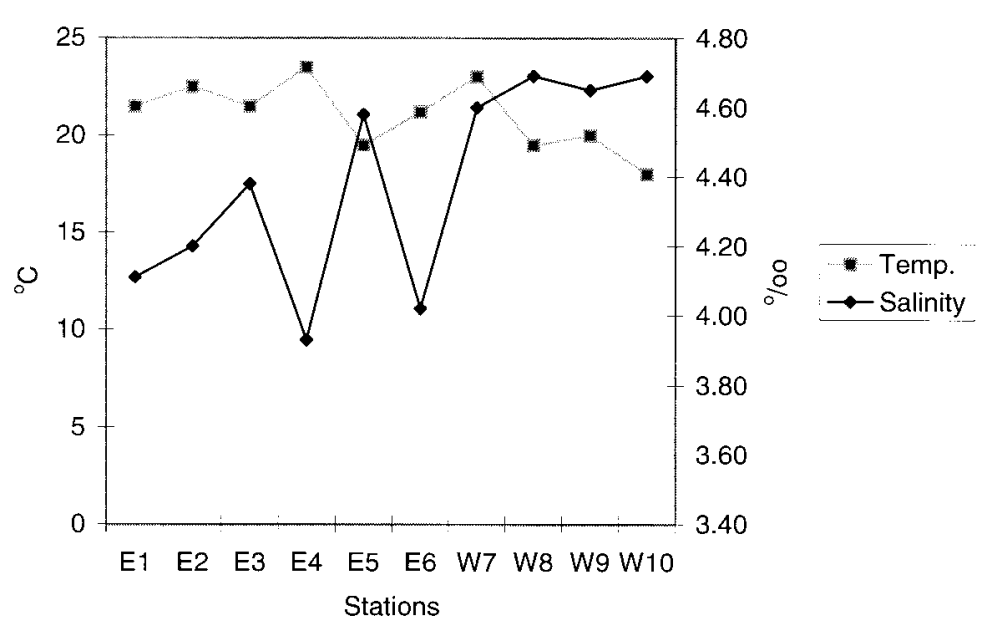

Fig. 2. Temperature and salinity at the shallow coastal zone stations on 7-9 July 1999. 


\section{Zooplankton communities}

A total of 24 species were found in the zooplankton communities of the study area in the pelagic part and the littoral zone. During the warm period, when the water column is stratified by a thermocline, the structure of zooplankton communities showed typical horizontal and vertical heterogeneity in the pelagic part of the Gulf. In July 1997 the highest zooplankton abundance and biomass (507 145 ind. $\mathrm{m}^{-3}$ and $4844 \mathrm{mg} \mathrm{m}^{-3}$, respectively) were found in the central part of the Gulf of Riga with the dominance of the cladoceran Bosmina c. maritima above the thermocline (91\% of the total mesozooplankton abundance). At the eastern transect of the Gulf the dominant species was the rotifer Keratella quadrata, whereas Synchaeta monopus and S. baltica dominated in the western part where the lowest total zooplankton density and biomass values (35 765 ind. $\mathrm{m}^{-3}$ and $317 \mathrm{mg} \mathrm{m}^{-3}$ ) during this survey were registered. Below the thermocline the copepods Eurytemora affinis and Acartia bifilosa were more abundant.

The same species, but in different proportions, dominated in August 1998. The maximum values of different zooplankton groups (Rotatoria 428486 ind. $\mathrm{m}^{-3}$, $469 \mathrm{mg} \mathrm{m}^{-3}$ and Cladocera 239784 ind. $\mathrm{m}^{-3}, 2415 \mathrm{mg} \mathrm{m}^{-3}$ ) were observed in the upper, warm water layer at the eastern part of the Gulf.

Although the total zooplankton abundance decreased at all transects of the Gulf of Riga in autumn, the variation of dominating groups (Copepoda, Rotatoria) between stations was high (from 21957 ind. $\mathrm{m}^{-3}$ to 151887 ind. $\mathrm{m}^{-3}$ and $223 \mathrm{mg} \mathrm{m}^{-3}$ to $934 \mathrm{mg} \mathrm{m}^{-3}$ ).

During the investigation period the density of Cercopagis pengoi populations fluctuated between 0 to 474 ind. $\mathrm{m}^{-3}$ in the pelagic part of the Gulf with higher abundance recorded at a depth of 30-40 m.

In the littoral zone the mean density and biomass of the total zooplankton were twice as high along the eastern part as in the western part (40259 and 22722 ind. $\mathrm{m}^{-3}, 613$ and $265 \mathrm{mg} \mathrm{m}^{-3}$, respectively) in July 1999. At stations without $C$. pengoi the main dominant species were the rotifers Keratella quadrata and K. cochlearis, the cladoceran Bosmina c. maritima, and early copepodite stages, as well as nauplii of Eurytemora affinis and Acartia bifilosa. At the station with the highest abundance of $C$. pengoi the density of small zooplankton (Keratella spp., copepod nauplii) was 55 times lower compared with the neighbouring station (950 ind. $\mathrm{m}^{-3}$ and 52001 ind. $\mathrm{m}^{-3}$; Table 1). At the station with the highest density of $C$. pengoi also the maximum number of ciliates $\left(31520\right.$ cells $\mathrm{L}^{-1}$ ) was observed. This indicates that ciliates have lost their main consumers - rotifers and nauplii (E. Boikova, unpublished data). 
Table 1. Plankton sampling protocol. Abundance (ind. $\mathrm{m}^{-3}$ ) in neighbouring littoral stations in the eastern part of the Gulf of Riga with the highest and lowest density of Cercopagis pengoi (E3 and E2) and without $C$. pengoi (E1) in July 1999. Potential food sources for $C$. pengoi are underlined

\begin{tabular}{|c|c|c|c|}
\hline \multirow{2}{*}{ Species } & \multicolumn{3}{|c|}{ Station and date } \\
\hline & E3, 7.07.1999 & E2, 7.07.1999 & E1, 9.07.1999 \\
\hline \multicolumn{4}{|l|}{ COPEPODA } \\
\hline Acartia bifilosa & 6325 & 240 & 834 \\
\hline Eurytemora affinis & 2625 & 880 & 3500 \\
\hline Cyclops sp. & 25 & 10 & 333 \\
\hline Copepoditae I-V & 850 & 900 & 70750 \\
\hline Nauplii & $\underline{175}$ & 1620 & $\underline{28167}$ \\
\hline \multicolumn{4}{|l|}{ CLADOCERA } \\
\hline Bosmina o. maritima & 9500 & 260 & 167 \\
\hline Bosmina sp. & - & 90 & - \\
\hline Podon polyphemoides & - & 70 & 167 \\
\hline Chydorus sphaericus & - & 60 & - \\
\hline Diaphanosoma brachyurum & 50 & - & - \\
\hline Cercopagis pengoi & 5790 & 10 & $\mathbf{0}$ \\
\hline \multicolumn{4}{|l|}{ ROTATORIA } \\
\hline Keratella cochlearis & $\underline{50}$ & 1080 & $\underline{5667}$ \\
\hline K. quadrata & $\underline{2 \overline{75}}$ & $\underline{640}$ & $\underline{17500}$ \\
\hline K. cruciformis & - & 70 & 667 \\
\hline Synchaeta baltica & 25 & 20 & - \\
\hline Brachionus quadridentatus & 50 & 510 & 667 \\
\hline B. urceus & - & 10 & - \\
\hline Brachionus sp. & - & 10 & 167 \\
\hline Euchlanis dilatata & - & 540 & 2167 \\
\hline Notholca acuminata & - & 20 & 500 \\
\hline CILIATES & $3152 \times 10^{4}$ & $872 \times 10^{4}$ & $312 \times 10^{4}$ \\
\hline
\end{tabular}

\section{Distribution and population structure of Cercopagis pengoi}

C. pengoi was found in about $60 \%$ of the sampled stations. It was present at abundances of 0-68 ind. $\mathrm{m}^{-3}$ above the thermocline and $0-10$ ind. $\mathrm{m}^{-3}$ beneath it on 17-28 July 1997 . The highest $C$. pengoi densities were found at the deepest stations on the central and western transects (Fig. 1). Juveniles made up more than half of the populations (64-76\%). The share of parthenogenetic females was $24-31 \%$, whereas males formed less than $9 \%$ of the populations. At the station with the highest $C$. pengoi abundance $\left(68\right.$ ind. $\mathrm{m}^{-3}$ ) juveniles made up $94 \%$ of the population. On 1-10 October 1997 C. pengoi was still present in plankton in low densities $\left(0-10\right.$ ind. $\left.\mathrm{m}^{-3}\right)$, mainly in the western part of the Gulf. The population was almost entirely composed of juvenile individuals. 
Densities of $C$. pengoi fluctuated between 1 and 474 ind. $\mathrm{m}^{-3}$ on $13-28$ August 1998. C. pengoi was present throughout the water column in all stations, but its distribution (Fig. 3) and population structure were not uniform. The highest observed abundance and biomass values (474 ind. $\mathrm{m}^{-3}$ and $142.2 \mathrm{mg} \mathrm{m}^{-3}$ ) were found in the uppermost $(0-4 \mathrm{~m})$ water layer in the pelagial of the eastern part of the Gulf of Riga. In this layer the $C$. pengoi population consisted of juveniles $(92 \%)$ and parthenogenetic females $(8 \%)$. The highest water temperature $\left(17.6^{\circ} \mathrm{C}\right)$ in this surface water layer was observed in August 1998; it was by about $1{ }^{\circ} \mathrm{C}$ lower in the layer just above the thermocline. In parallel C. pengoi density decreased to 31 ind. $\mathrm{m}^{-3}$ with the proportion of adults increasing to $31 \%$. Below the thermocline, the population density was only 6 ind. $\mathrm{m}^{-3}$, made up of females only (67\% parthenogenetic and 33\% gamethogenetic).

An exception was observed at one station in the central part of the Gulf where the pattern was reversed: below the thermocline the C.pengoi density was 99 ind. $\mathrm{m}^{-3}$ and above it 48 ind. $\mathrm{m}^{-3}$. In both layers (above and below the thermocline) the structure of Cercopagis populations was similar: $67 \%$ juveniles, $26 \%$ parthenogenetic females, $6 \%$ gamethogenetic females, and $1 \%$ males and $60 \%$ juveniles, $27 \%$ parthenogenetic females, $12 \%$ gamethogenetic females, and $1 \%$ males, respectively.

In the littoral zone, $C$. pengoi was encountered only at three eastern stations (E2, E3, E5) where its densities fluctuated between 10 and 5790 ind. $\mathrm{m}^{-3}$ (Fig. 4). The maximum was registered at the littoral station E3 with surface water temperature $21.5^{\circ} \mathrm{C}$ and salinity $4.38 \%$. Although at this station the structure of the C.pengoi population showed dominance of juveniles (92\%), the total biomass of $1737.0 \mathrm{mg} \mathrm{m}^{-3}$, made it the dominating plankter by biomass. At the two other stations C.pengoi were recorded at abundances of 160 (E5) and 10 (E2) ind. $\mathrm{m}^{-3}$ forming $33 \%$ of the biomass of the Cladocera group.

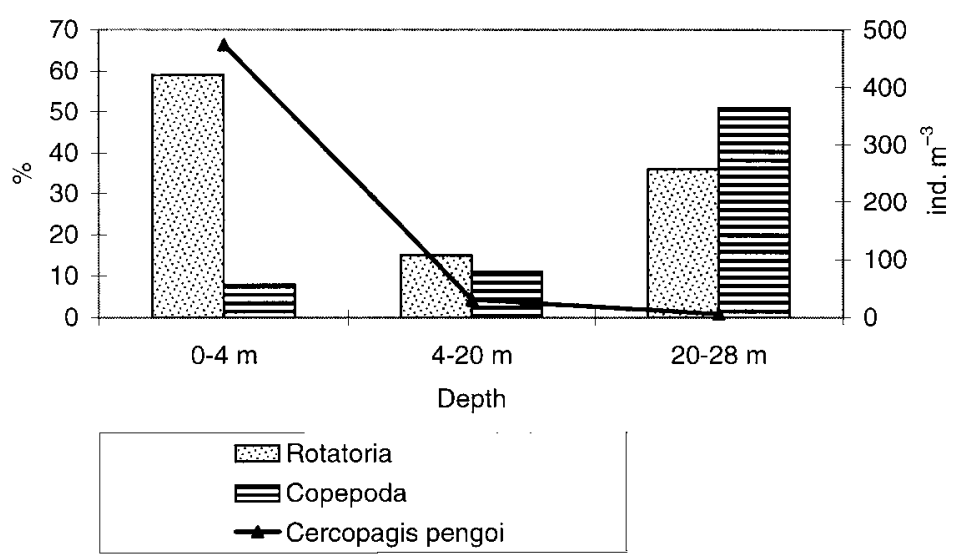

Fig. 3. Vertical distribution of Cercopagis pengoi, Rotatoria, and Copepoda at the eastern transect station E3 at $30 \mathrm{~m}$ depth in the Gulf of Riga. 


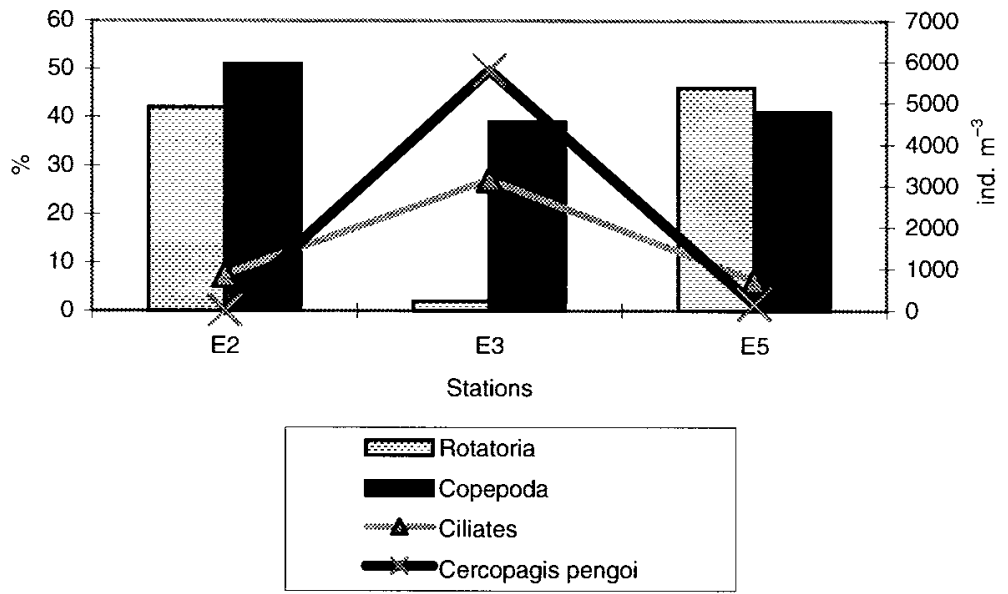

Fig. 4. Abundance of micro- and mesozooplankton groups at three littoral zone stations with Cercopagis pengoi on 7-8 July 1999.

At the eastern littoral station (E3), the highest abundance of C.pengoi coincided with the lowest densities of rotifer and copepod nauplii. No such relationship between smaller zooplankton and $C$. pengoi was recorded at the other two stations.

\section{DISCUSSION}

The maximum abundance and biomass values of $C$. pengoi registered in the littoral zone of the Gulf of Riga (5790 ind. $\mathrm{m}^{-3}$ and $1737.0 \mathrm{mg} \mathrm{m}^{-3}$ ) are higher than those reported from other parts of the Baltic Sea. The highest observed abundance in the shallow coastal area of the Gulf of Gdansk is 1369 ind. $\mathrm{m}^{-3}$ (Bielecka et al., 2000), in the Gulf of Finland from 300-305 ind. $\mathrm{m}^{-3}$ (Krylov et al., 1999; Antsulevich \& Välipakka, 2000) to about 1800 ind. $\mathrm{m}^{-3}$ (Uitto et al., 1999), and in a Swedish coastal area (Himmerfjärden) 420 ind. $\mathrm{m}^{-3}$ (Gorokhova et al., 2000). A very intense development of cladocerans is characteristic of the summer mesozooplankton of the Gulf of Riga. Depending on water temperature, the maximum abundance of Bosmina can occur from July to the first half of September (Line \& Sidrevics, 1995). Water temperature above $20^{\circ} \mathrm{C}$ seems to be optimal for parthenogenetic development of C. pengoi in the Gulf of Riga. In the upper warm water layer, populations mostly consist of juveniles even in October with water temperature of $10.7^{\circ} \mathrm{C}$. During our investigation periods, salinity fluctuated between 3.84 and $6.59 \%$. Such and also wider tolerance of temperature and salinity were found in other Baltic Sea areas (Krylov et al., 1999; Gorokhova et al., 2000). 
Fast parthenogenetic reproduction can form large densities of C. pengoi. Similarly to the Gulf of Finland, C. pengoi was noted to clog fishing nets in the coastal zone of the Gulf of Riga (Kondratjeva, 2000). During the investigation period of 1997-99, the density of $C$. pengoi increased from 10 to 5790 ind. $\mathrm{m}^{-3}$. This development suggests that the abundance of $C$. pengoi in the Gulf of Riga could be higher in the next warm summers. Moreover, this newcomer may also affect food resources for fish. Cercopagis species are predators and consume rotifers and crustaceans (Mordukhaj-Boltovskoj, 1969). In general, the mesozooplankton in the Gulf of Riga is composed of comparatively small organisms, especially in the shallow coastal zone, where rotifers can contribute up to $80 \%$ of the total mesozooplankton abundance (Strākse, 2000). Uitto et al. (1999) estimated that at $18^{\circ} \mathrm{C}, \mathrm{C}$. pengoi with a density of about 2000 ind. $\mathrm{m}^{-3}$ would consume onethird of the zooplankton biomass. This may mean that at a density of 5000 ind. $\mathrm{m}^{-3}$ C. pengoi has already modified the trophic web of microzooplankton. Indeed, the lowest abundance of rotifers and copepod nauplii was observed at the littoral station E3. Also, the recorded highest ciliate densities confirm loss of their predators, in this case rotifers.

The highest densities of $C$. pengoi populations were found in the eastern part of the Gulf of Riga. Total zooplankton abundances were higher in the central and south-eastern parts of the Gulf. In the open part of the Gulf, Copepoda and Cladocera often account for a greater share of mesozooplankton abundance. Rotatorians play a more important role in the coastal areas, especially in the southern part of the Gulf of Riga, in the outflow region of the Daugava River, where these organisms could show highest population densities (Ikauniece \& Ceitlina, 1998; Strākse, 2000). Therefore, abundant availability of food in the southeastern part of the Gulf of Riga can often create optimal environmental conditions for $C$. pengoi. These large crustaceans often become the main prey object for plankton-feeding fish, even if the density of the species in plankton is low (Ojaveer \& Lumberg, 1995; Antsulevich \& Välipakka, 2000).

In the Gulf of Riga depth is apparently not a primary factor limiting the spatial distribution of $C$. pengoi unlike in the open Baltic where maximum abundances were found at depths of 50-70 m (Gorokhova et al., 2000). The maximum abundance of $C$. pengoi observed in the littoral zone at $1 \mathrm{~m}$ depth exceeded the respective values in the pelagic part of the Gulf of Riga. In the pelagic part, highest abundances were found above the thermocline at depths of $30-40 \mathrm{~m}$. This is in disagreement with highest water temperatures and maximum density of the cladoceran Bosmina c. maritima in the central part of the Gulf of Riga. Such spatial distribution of $C$. pengoi in the open part of the Gulf is difficult to explain with food resources or water temperature.

Nonindigenous species can successfully invade new habitats if these territories are under higher stress due to anthropogenic impacts or climatic changes. Plankton species are mainly introduced through shipping, and it is almost certain that C. pengoi was introduced into the Baltic Sea by ballast water. Most major ports in the world are located at river mouths and the salinity of these harbours is similar to the Baltic Sea areas (Gollasch \& Leppäkoski, 1999). At the end of the 1970s, 
when the river inflow increased, an intense salinity decline started in the Gulf of Riga, which reached the lowest values in 1992 (Berzinsh, 1995). Restructuring of the nutrient pool in the 1990s - depletion of the N and Si pools and increasing $\mathrm{P}$ concentrations - reshaped the plankton communities, resulting in changes of foodweb relationships and decrease of zooplankton biomass (Yurkovskis et al., 1999). During this time period, the structure and spatial distribution of zooplankton communities changed in the Gulf of Finland and Neva Bay. The dominance of the rotifer Asplanchna priodonta in the zooplankton and blue-green algae in the phytoplankton communities are the response of aquatic communities to anthropogenic stress (Telesh, 1995; Telesh et al., 1999). In summer 1991 C. pengoi was first recorded in the coastal zone of the southern part of the Gulf of Riga (HELCOM, 1996). In Estonian coastal waters it was first found in 1992 in the north-east Gulf of Riga and Pärnu Bay (Ojaveer \& Lumberg, 1995). At present this species is distributed in the whole Gulf of Riga, including its littoral, western, and central parts, with highest densities in the eastern littoral zone.

Because of its very intense reproduction, C. pengoi forms permanent populations from July to October. Differences in the level of eutrophication between the eastern and open parts of the Gulf of Riga may be one of the most important factors responsible for the highest microzooplankton abundances at the eastern stations. Since the highest density of C. pengoi of 5790 ind. $\mathrm{m}^{-3}$ was recorded at an eastern station, this predator could change the trophic web of microzooplankton there. The density of rotifers and copepod nauplii at this littoral station was the lowest and an indirect positive effect on ciliates was recorded. Considering the possibility that the density of $C$. pengoi may further increase, this newcomer species can essentially affect the community structure of meso- and microzooplankton and their trophic relationships. Moreover, the overall energy balance, organic matter transport, and food web efficiency in the Gulf of Riga may be affected as well.

\section{ACKNOWLEDGEMENTS}

This study was financially supported by the Latvian Council of Science project "Seasonal processes and mechanisms in the turnover of biotic material in the Gulf of Riga" (1997-2001) and the programme "Biological resources of ecosystems of Latvia, and optimization of their rational use" (1995-2002). The author is very grateful to Dr. Elmira Boikova for critical reading of and comments on the manuscript.

\section{REFERENCES}

Antsulevich, A. \& Välipakka, P. 2000. Cercopagis pengoi - new important food object of the Baltic herring in the Gulf of Finland. Internat. Rev. Hydrobiol., 85, 609-619.

Berzinsh, V. 1995. Hydrological regime. In Ecosystem of the Gulf of Riga between 1920 and 1990 (Ojaveer, E., ed.), pp. 7-31. Estonian Acad. Publ., Tallinn. 
Bielecka, L., Zmijewska, M. I. \& Szymborska, A. 2000. A new predatory cladoceran Cercopagis (Cercopagis) pengoi (Ostroumov 1891) in the Gulf of Gdansk. Oceanologia, 42, 371-374.

BMB WG NEMO. 2001. Baltic Marine Biologists Working Group on Nonindigenous Estuarine and Marine Organisms. Alien Species Directory (Olenin, S. \& Leppäkoski, E., eds.) http://www.ku.1t/nemo/alien_species_directory.htm (visited 2001-06-04).

Gollasch, S. \& Leppäkoski, E. 1999. Risk Assessment of Alien Species in Nordic Coastal Waters. Nord, Copenhagen.

Gorokhova, E., Aladin, N. \& Dumont, H. I. 2000. Further expansion of the genus Cercopagis (Crustacea, Brachiopoda, Onychopoda) in the Baltic Sea, with notes on the taxa present and their ecology. Hydrobiologia, 429, 207-218.

HELCOM. 1996. New species. In Third Periodic Assessment of the State of the Marine Environment of the Baltic Sea, 1989-1993. Background Document. Balt. Sea Environ. Proc., 64B, 73.

Ikauniece, A. \& Ceitlina, M. 1998. Long-term dynamics of zooplankton in environmental risk zones of the Gulf of Riga. Proc. Latvian Acad. Sci., Section B, 52, 62-67.

Jansson, K. 1994. Alien species in the marine environment. Swedish Environment Protection Agency. Report 4357, 67.

Kondratjeva, N. 2000. Vai vēzītis - ieceļotājs ietekmē zveju Baltijas jūras piekrastē. In Latvijas zivsaimniecības gadagrāmata 2000, pp. 105-107. BIOTA, Rīga.

Krylov, P. I., Bychenkov, D. E., Panov, V. E., Rodionova, N. V. \& Telesh, I. V. 1999. Distribution and seasonal dynamics of the Ponto-Caspian invader Cercopagis pengoi (Crustacea, Cladocera) in the Neva Estuary (Gulf of Finland). Hydrobiologia, 393, 227-232.

Lagzdins, G. \& Pallo, P. 1994. Marenzelleria viridis (Verrill) (Polichaeta, Spinoidae) - a new species for the Gulf of Riga. Proc. Latvian Acad. Sci., Section B, 43, 184-188.

Leppäkoski, E. J. 1984. Introduced species in the Baltic Sea and its coastal ecosystems. Ophelia, 3, 123-135.

Leppäkoski, E. J. 1991. Introduced species - resource or threat in brackish-water seas? Examples from the Baltic and the Black Sea. Mar. Poll. Bull., 23, 219-223.

Line, R. \& Sidrevics, L. 1995. Zooplankton of the Gulf of Riga. In Ecosystem of the Gulf of Riga between 1920 and 1990 (Ojaveer, E., ed.), pp. 175-186, Estonian Acad. Publ., Tallinn.

Mordukhaj-Boltovskoj, F. D. 1969. Order Cladocera. In Guide for Identification of the Fauna of the Black and Azov Seas. Vol. 2. Freeliving Invertebrates. Crustaceans (Vodyanitskij, V. A., ed.), pp. 12-31. Naukova Dumka, Kiev (in Russian).

Nikolaev, I. I. 1951. On new introductions in fauna and flora of the North and the Baltic seas from distant areas. Zool. zh., 30, 556-561 (in Russian).

Ojaveer, H. 1997. Environmentally induced changes in distribution of fish aggregations on the coastal slope in the Gulf of Riga. In Proceedings of the 14th Baltic Marine Biologists Symposium (Ojaveer, E., ed.), Pärnu, Estonia, 5-6 August 1995, pp. 170-183.

Ojaveer, H. \& Lumberg, A. 1995. On the role of Cercopagis (Cercopagis) pengoi (Ostroumov) in Pärnu Bay and the NE part of the Gulf of Riga ecosystem. Proc. Estonian Acad. Sci. Ecol., $\mathbf{5}, 20-25$.

Ojaveer, H., Simm, M., Lankov, A. \& Lumberg, A. 2000. Consequences of invasion of a predatory cladoceran. ICES CM 2000/U:16.

Pallo, P., Windboum, B. \& Olafsson, E. 1998. A quantitative survey of the benthic meiofauna in the Gulf of Riga (Eastern Baltic Sea), with special reference to the structure of nematode assemblages. Ophelia, 49, 117-139.

Segerstråle, S. G. 1957. Baltic Sea. In Treatise on Marine Ecology and Paleoecology I. Ecology. Geol. Soc. Am. Mem. (Hedgpeth, J. W., ed.), 67, 751-800.

Strākse, S. 2000. Variations of mesozooplankton species composition, abundance, and biomass in the littoral zone of the Gulf of Rìga, Latvia. Proc. Latvian Acad. Sci., Section B, 54, 155-159.

Tenson, J. 1995. Phytoplankton of the Pärnu Bay. In Ecosystem of the Gulf of Riga between 1920 and 1990 (Ojaveer, E., ed.), pp. 105-126. Estonian Acad. Publ., Tallinn. 
Telesh, I. V. 1995. Rotifer assemblages in the Neva Bay, Russia: principles of formation, present state and perspectives. Hydrobiologia, 313/314, 57-62.

Telesh, I. V., Alimov, A. F., Golubkov, S. M., Nikulina, V. N. \& Panov, V. E. 1999. Response of aquatic communities to anthropogenic stress: a comparative study of Neva Bay and the eastern Gulf of Finland. Hydrobiologia, 393, 95-105.

Uitto, A., Gorokhova, E. \& Välipakka, P. 1999. Distribution of the non-indigenous Cercopagis pengoi in the coastal waters of the eastern Gulf of Finland. ICES J. Mar. Sci., 56, Supplement, 49-57.

Yurkovskis, A., Kostrichkina, E. \& Ikauniece, A. 1999. Seasonal succession and growth in the plankton communities of the Gulf of Riga in relation to long-term nutrient dynamics. Hydrobiologia, 393, 83-89.

\title{
Cercopagis pengoi (Ostroumov) populatsiooniline struktuur ja tema osakaal Liivi lahe mesozooplanktoni koosluses
}

\begin{abstract}
Solvita Strake
Hiljutine tulnukliik, röövtoiduline vesikirp Cercopagis pengoi moodustab püsivaid asurkondi üle kogu Liivi lahe. Uurimisperioodil (1997-1999) suurenes C. pengoi arvukus, kusjuures suurim näitaja (5790 isendit $\mathrm{m}^{-3}$ ) registreeriti kaldaäärses vees. Kõige ohtramalt oli isendeid Liivi lahe idaosas, kus veetemperatuur oli kõrgeim ning soolsus madalaim. C. pengoi arvukus oli suurem ülalpool sesoonset termokliini võrreldes alaosaga, üle $50 \%$ populatsioonist moodustasid noored isendid. Soojas ülakihis $(0-4 \mathrm{~m})$ ulatus noorte osakaal isegi kuni $92 \%$-ni. C. pengoi võib piirata mikrozooplanktoni populatsiooni arvukust Liivi lahe kaldaäärses piirkonnas, sest tema toiduks on keriloomad ja aerjalaliste vastsed.
\end{abstract}

